Bangladesh J. Bot. 48(3): 567-573, 2019 (September)

\title{
MORPHOLOGICAL DEVELOPMENT OF LILY (LILIUM 'SIBERIA') FLORAL ORGANS
}

\author{
Zhang Zheng-Yao, LiU Xiao-Feng ${ }^{1}$, Zhao Chang-Wei ${ }^{2}$, Lyu Xin-Yu, \\ Li Wan-Qing, Sun Wen And Xu Pin-San \\ School of Life Science and Medicine, Dalian University of Technology, \\ Panjin, Liaoning 124221, China
}

Keywords: Morphological, Lily, Floral organ, Petal, Epidermal cells

\begin{abstract}
Effects of flower buds of oriental lily "Siberia", Asian Lily "Desert Storm" and "Shuttle Red" on the growth and development during different developmental stages of plants were investigated. The results showed that the plant height of different lily was not different in different periods, and the growth increased rapidly during seeding stage to squaring period while slowly in the squaring period to full-bloom stage. The size of flower organs was different, the "Siberia" was significantly larger than "desert storm" and "shuttle red", and the development of ovary and anther was earlier. The intraepidermal of epidermal cells of lily petals were smaller than those of outer epidermal cells. The number of intraepidermal cells is much more higher than the number of outer epithelial cells. The infiltration degree of lily petals was related to the growth of intraepidermal and outer epidermal cells of petals. The growth rate of intraepidermal cells in "Siberia" was significantly higher than that in outer epidermal. The growth rate of intraepidermal cells in "desert storm" and "shuttle red" was slightly higher than that of outer epidermal, which proved that the uneven growth of petals of intraepidermal and outer epidermal cells leads to lily petals' bent, thereby results in the formation of different flower types.
\end{abstract}

\section{Introduction}

Lilium sp. is a perennial herb of liliaceous plants, which is popular and becomes a rookie in the rapid development of flower market at home and abroad because of its beautiful flowers, unique flavor (Liu et al. 2011). Among which, the flower pattern is one of the three important factors that constitute the ornamental plant character (Dai et al. 2013). Recently, the research on lily flower types mainly focuses on the morphological differentiation of flower buds and the internal and external factors (Guo et al. 2006). Whereas, there are scanty researches about the floral organ developmental regularity, after the completion of flower bud differentiation (Xu and Tang 2011)

Ren conducted computer simulation studies on lily patterns (Ren et al. 2009). On floral pattern molecular genetics, flower organ development has been rapidly developed in recent years. More mature experimental models have been used to conduct the research, which is the ABC model (Hu et al. 2007, Kawabata et al. 2011) found that the formation of corolla was related to the process of petal dilation. In different regions of the petal, the cells increased in different ways (Wang et al. 2014).

The law of the differences in the varieties of the lily growth and flower organ morphology development were investigated. Through the microscopic observation of flower buds in different developmental stages, the inside of the flower buds, the petal epidermal cells and the phenomenon of the petal bendings' rule.

*Author for correspondence: <zhengyaozhang@dlut.edu.cn>. ${ }^{1}$ Department of Laboratory Medicine, Jilin Cancer Hospital, HuGuang Road, Changchun Jilin 130021, China. ${ }^{2}$ Department of Orthopedics, Affiliated Hospital of Changchun University of Chinese Medicine, GongNong Road, Changchun Jilin 130021, China 


\section{Materials and Methods}

The experimental materials were Oriental "Siberian" Lily, Asian "Desert Storm" Lily, and "Shuttle red "Lily. The bulbs averaged $6.6 \mathrm{~cm}, 6.0 \mathrm{~cm}$ and $3.6 \mathrm{~cm}$ in diameter, respectively and were planted in pots in April 2015 (Fig. 1). The experiment was conducted under indoor conditions $\left(25 \sim 37^{\circ} \mathrm{C}\right)$, from June to August, 2015.
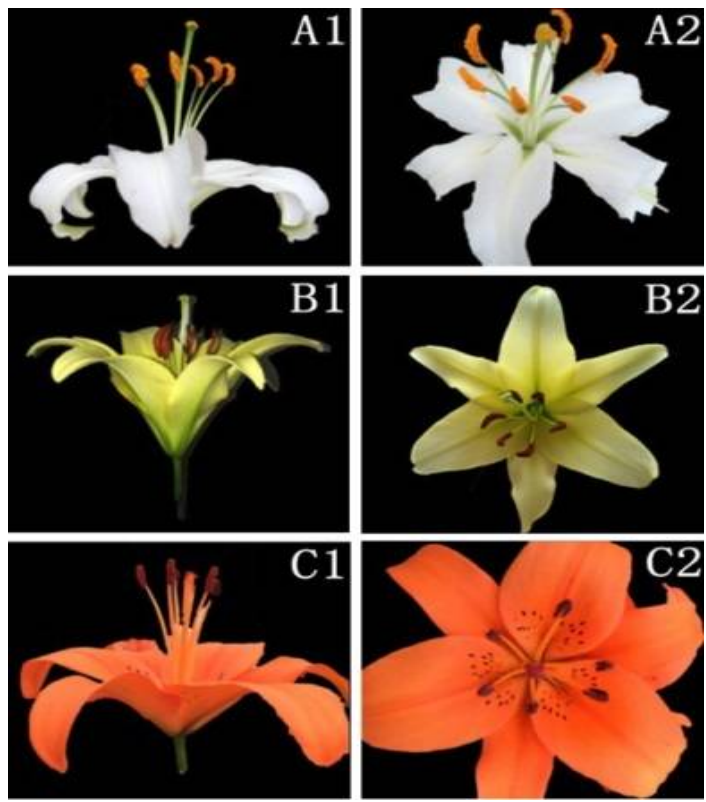

Fig.1. Shapes of lily's corolla. A. Siberia, B. Desert Storm and C. Shuttle Red.

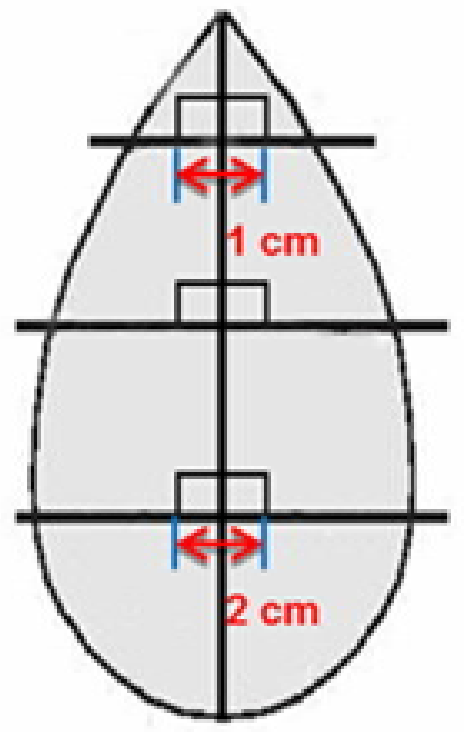

Fig. 2. Streaking survey of lily's petal growth. 
After the lily bulbs were planted, the height of each lily cultivar was measured at the emergence, budding, and flowering stages. The average value was used to compare the differences in the height of the cultivars. When the flower buds were planted, the flower buds of different sizes were taken and their internal development under a dissecting microscope was observed to count the differences in bud development among different varieties.

The petals were removed at full flowering stage, and the inner and outer epidermis of the petals were harvested. The morphology of the cells were studied under the microscope after dying and analyzed the epidermal growth of petals in different varieties.

When the flower buds opened, the petals were peeled by drawing lines. A black marker was used to draw small squares $0.5 \mathrm{~cm}$ on the inner and outer tips of the petals, with small squares 1.0 $\mathrm{cm}$ on the center and bottom, respectively. When the flowers were in full bloom, the marked petals were removed, then the horizontal and vertical growth of each part of the petals were measured and analyzed the relative growth of each variety of cells.

\section{Results and Discussion}

When the flower buds were planted, all varieties of lily showed the same trend of growth. They had the rapid growth from the emergence to budding period, budding to flowering period grew slowly, and full to the end of flowering had little growth. From the point of the lily variety, after the budding stage, "Desert Storm" plant had the higher growth rates and higher height than "Siberia" and "shuttle red" (Fig. 3).

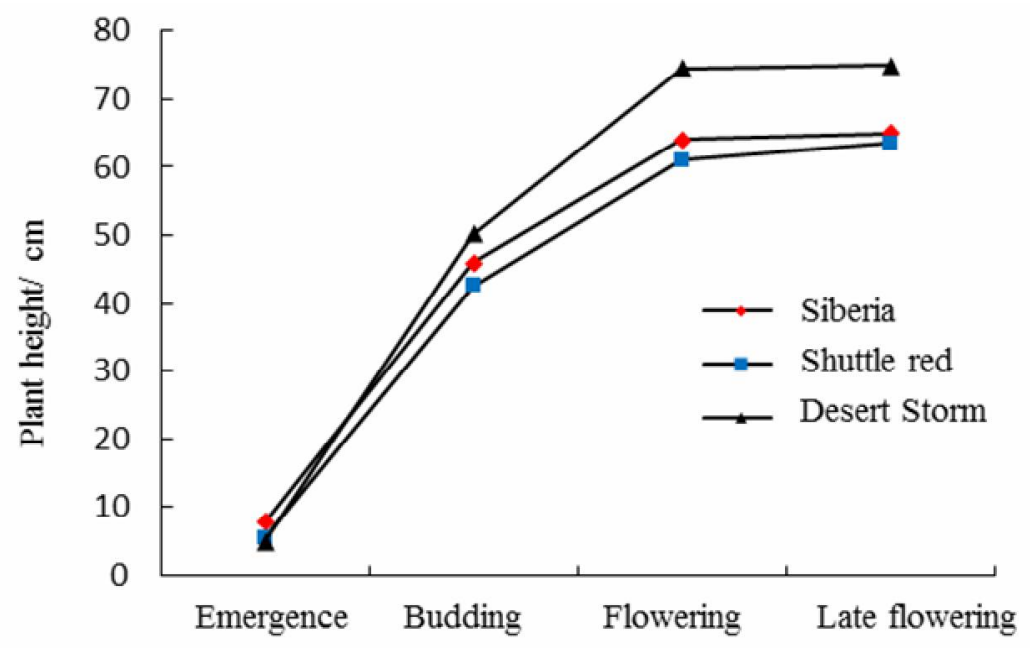

Fig. 3. Plant height of lily buds at different developmental stages.

The flower buds were collected at the same time during the budding period. The flower buds were different in different lily varieties, with the largest in "Siberia", the second in "shuttle red" and the least in "Desert storm". Microscopic observation showed that flower buds in the development process increased with the growth of flower organs; petals and calyx growth tendency keep the same length with the flower buds. Stamens and pistils decreased gradually in the late budding growth rate, and tended to smooth. The anther and ovary of "Siberia" matured earlier than the other two varieties (Fig. 4). 

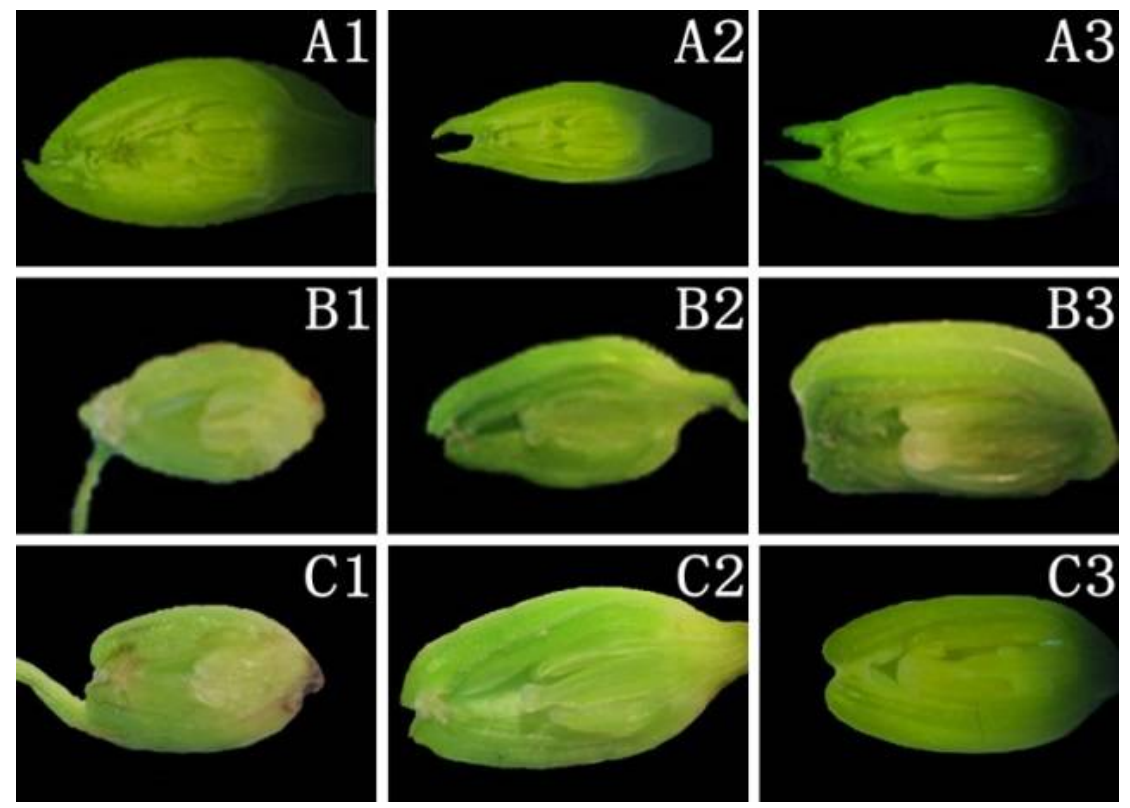

Fig. 4. Bud's internal structure in different periods.

Buds of "Siberia" 1, 1.5 and $2 \mathrm{~cm}$, respectively (A1-A3). Buds of "Desert Storm" 0.4, 0.7 and $1.0 \mathrm{~cm}$ respectively (B1-B3). Buds of "Shuttle red" $0.5,1.0$ and $1.5 \mathrm{~cm}$, respectively $(\mathrm{C} 1-\mathrm{C} 3)$.

Fig. 5 showed that the outer epidermal cells are larger than the inner epidermal cells in all lilies. In "Siberia", the number of inner epidermal cells is much higher than the outer epidermis, and the shape of the outer epidermis is more elongated, and the "Siberian" petals bend more outwardly. The inner and outer epidermal cells in "Desert Storm" are similar in shape, and the number is higher than "Siberia". "Desert Storm" has the lightest curvature of the petals. "Shuttle red" epidermal cells are coarse and smaller than "Siberia" in the number, with the middle degree of petal bending.

It was observed that the curvature of the lily petals is affected by the number and shape of the cells. Fig. 6 showed that the petal medial growth is greater than petal lateral growth. it was also revealed that the number and the uneven growth of petal cells resulted in a difference in length, which in turn lead to the bending of the petals (Fig. 5).

The comparison of the different corolla shapes and the petals regional growth pattern showed that the mechanism of regulating three-dimensional shape of the corolla is due to uneven distribution of petal cells. Therefore, finding out the genes which regulate cell expansion and division, and optimizing the pattern according to needs will have prospect that would grow special pattern lily flower according to preference. Lily petal bending process is used because of the different rates of petals growth both inside and outside. The area and number of epidermal cells inside and outside lead to the amount of petal growth.

The plant height variation of lily showed rapid growth, slow growth and basic stop in the whole growth period, and the growth rate was different with different species. The experiment showed that the stamens and pistils decreased gradually in the late budding stage, "Siberia" had earlier maturation of anther and ovary, which would help to determine the optimal pollination time. Through the observation of the inner and outer petal cells, the shape and number of them in 
different positions caused the petals to bend. Moreover, Kawabata et al. (2011) observed the cell morphology of five Eustoma flowers and found that there were differences in the positions of the petals and the differences between inside and outside cells. So, further study may be done with the relationship between petal curvature and cells in other varieties.
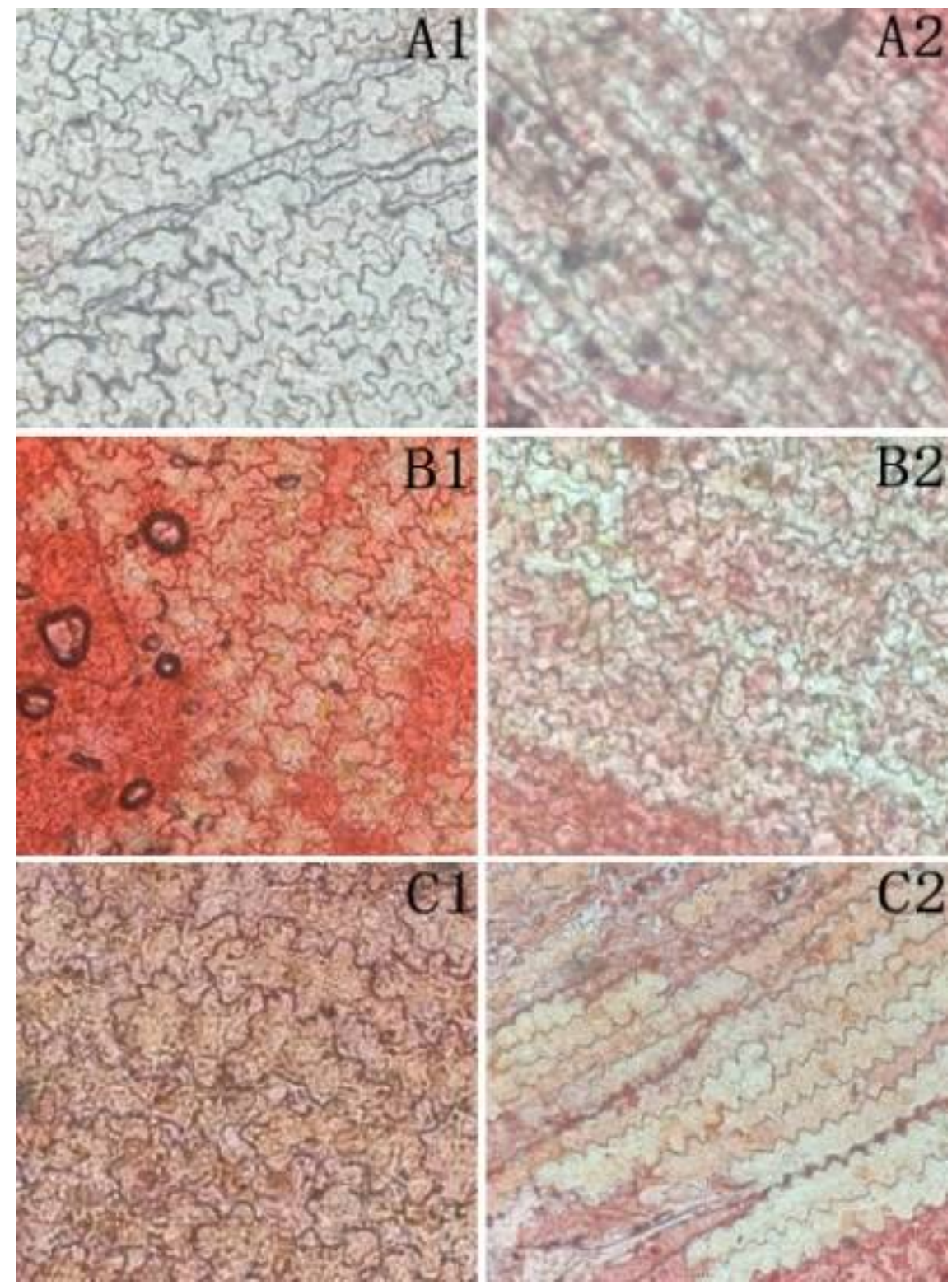

Fig. 5. Observation of epidermal cells of lily's petal.

A: Siberia, B: Desert Storm, C: "Shuttle red", 1. Inner epidermal of petal and 2. Outer epidermal of petal. 

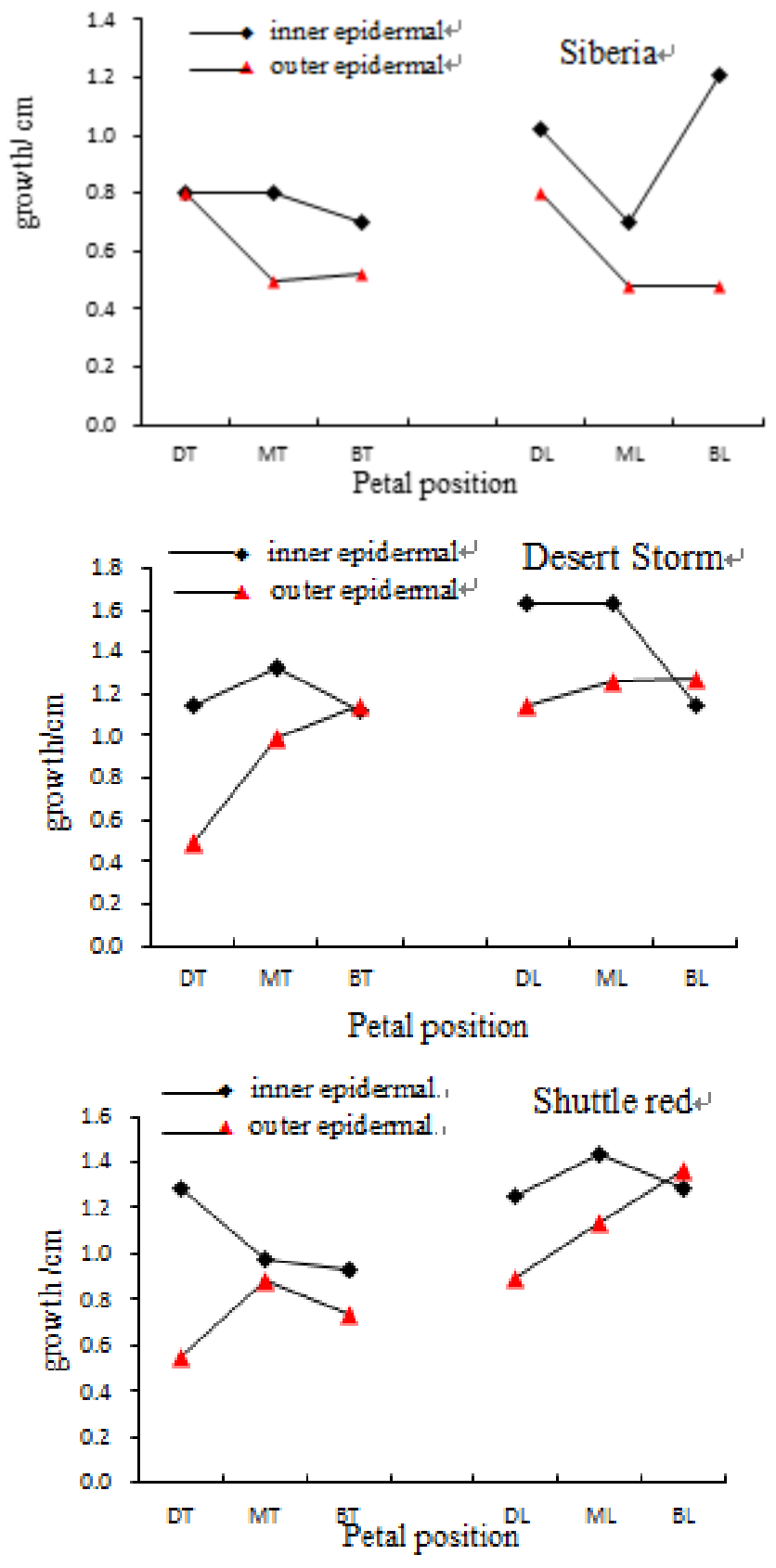

Fig. 6. Growth of Lily's petal.

DT. Top lateral, MT. Middle lateral, BT. Bottom lateral, DL. Top longitudinal, MT.

Central longitudinal and BT. Bottom longitudinal.

There was no difference between lily calyx and petals. A modified model ABC was proposed (Cong et al. 2007), in which B-functional genes were expressed not only in the second and third floral organs, but also in the first round. B function of gene regulated the growth and development 
of lily petals, and Zhang et al. (2003) isolated LfMADS (one of the B function genes from Lilium) by RT-PCR method, and constructed the binary vector pBin 438 to transform tobacco, to obtain the mutations in the gene plants with variant calyx (Zhao et al. 2007).

In general, there is still very few study on the morphological regulation of lily flower organs. The main research stays at the basic stage of gene cloning and functional identification. There is a long way to go after the development of lily flower organ.

\section{Acknowledgements}

The authors are grateful to the authorities of the National Natural Science Foundation of China (81503177, 81573999) and Jilin science and technology development plan project (20160101158JC) for financial support.

\section{References}

Cong N, Cheng ZJ and Wan JM 2007. The ABCDE model of organ development. Chinese Agric. Sci. Bulletin. 23(7).

Dai SL, Huang H, Fu JX and Hong Y 2013. Advances in molecular breeding of ornamental plants. Chinese Bulletin of Bot 48(6): 589-607.

Guo R, Zhao XY, Wang WH and Chen WZ 2006. Observation of morphological changes of lily bulb in bud differentiation periods. J. Shenyang Agricul. University 37(1): 31-34.

Hu FR, Xi ML, Liu GX, Chi J and Shi JS 2007. Study on organogenesis and somatic embryogenesis of oriental cily. J. Nanjing For University. pp 5-8.

Kawabata S, Nii K, Yokoo M. 2011. Three-dimensional formation of corolla shapes in relation to the developmental distortion of petals in Eustoma grandiflorum. Sci. Hort 132(1): 66-70.

Liu XX, Wu LF, Zhang YP, Jia WJ, Zhao PF and Cui GF 2011. The research progress of lily breeding trend and technology. ZHEJIANG EXUE 2: 287-290.

Ren ZF, Zhao XC, Wang JF, Wang LL and Li GH 2009. Application research of virtual flower modeling technology based on Onyx flower. Chinese Agri. Sci. Bulletin 25(4): 179-182.

Wang JY, Liu F, Su X, Lu ZY and Zhou YW 2014. Morphological and histological observation of flower bud differentation in the bulbs of Lilium pumilum. Pratacultural Sci. 31(05): 878-883.

Xu LP and Tang DC 2011. Study on morphological development of three kinds of lily. Northern Hort $\mathbf{1}$ : 86-88.

Zhang Y and Liu QL 2003. Proceedings on molecular mechanism of plant flower development. Chinese Bulletin Bot. 20(5): 589-601.

Zhao YQ, Mi ZW and Liu QL 2007. Construction of expression vector and function analysis of Lf MADS genes from Lilium. Acta Hort Sinica 34(2): 473-442.

(Manuscript received on 1 June, 2018; revised on 20 January 2019) 